\title{
Chapter 3 \\ A Faulty Foundation: Historical Origins of Formal Education Curriculum in Africa
}

An understanding of the present-day education curriculum in Africa- and its effects on Africans- must be rooted in an understanding of the different epochs the broader education sector in the region has passed through. The characteristics of these epochs will enlighten the interested student and enable a deeper analysis of the different factors and actors currently at play in education curriculum in Africa, south of the Sahara. This chapter will attempt a summarized review of selected historical literature on education in Africa with an emphasis on the evolution of the curricula.

\section{Education in Africa: From Ancient Times to the Dawn of Colonialism}

Several studies have established that contrary to widespread beliefs, formal, and informal education were actively in existence in Africa prior to the commencement of colonialism. At the formal, nonformal and informal levels, Africans in various parts of the continent were consistently involved in the business of transmitting knowledge to the younger generation. Walter Rodney asserts that "the colonizers did not introduce education into Africa, they introduced a new set of formal educational institutions which partly supplemented and partly replaced those which were there before" (London, Bogle L'Overture 1972, 263). In ancient times, education across Africa differed across ethnicities, all of which operated within various forms of economic, political, and social systems. Yet, there was identifiable unity in the culture of learning and in the way of knowledge transmission among these groups. The identifiable cultural homogeneity reflects in the traditional education which was available to the younger generation across black Africa. For instance, a great deal of importance and solemnity was attached to the passing on of knowledge from one generation to another. Education in most of traditional black Africa was also not done in isolation, but involved a collection of individuals, such as, age grade (Moumouni

C. Ezeanya-Esiobu, Indigenous Knowledge and Education in Africa, 
$1968,15)$. These groups of individuals were taught progressively as they grew in age and maturity, with their education emphasizing both the physical and metaphysical realities.

Abdou Moumouni in Education in Africa (Praeger: New York 1968), notes that although parents, nuclear and extended family members considered it their primary responsibility to ensure that their wards were well socialized according to the requirements of the society, traditional education in Africa also relied extensively on community effort. The high importance attached to education makes the popular African saying that "it takes a village to raise a child." One thing this ensures is that even children born to less privileged parents have as much opportunity to transcend their economic disadvantage by being taught by both the rich and the poor alike. Moumouni concedes that community oriented efforts give the appearance of an unstructured system that leaves such an issue as important as education to the whims and caprices of individuals within society, but he insists that far from being undecided and incoherent, education in Africa is so structured that, from the time of birth until adulthood, the individual is subjected to a well thought out plan of inculcation of values, discipline, education and all that is needed to ensure an adult who will be useful to the overall growth and development of society (Moumouni 1968, 16).

In the precolonial African education system, the baby is allowed to latch on to the mother from birth for as long as 6 years. It is beside the mother that the baby gets the full assurance of love and care, strong foundations needed to ensure a strong but empathic adult. The African woman is renowned for her unparalleled commitment to the health and well-being of her child, going to great lengths to ensure that he is strong, healthy, and well-behaved (Moumouni 1968, 16). At around the age of six, the boy child is completely weaned off his mother's care and attention, with the father assuming the main responsibility for his education. The girl child remains under the primary care of her mother. At this stage, the child is gradually introduced into the life of adults, and is called upon frequently to perform various tasks for adults within the community. The child also participates in games and role-playing which among other benefits, develop him intellectually, psychologically, and socially.

Education in Africa, it must be noted, is not distinct from life itself (Moumouni $1968,18)$. There is minimal emphasis on abstract learning or formalism as distinct from the day-to-day situations that individuals encounter. In this informal manner, the basic foundation of societal values, knowledge and culture are transmitted to the child. The young girl by assisting the mother to cook certain dishes, and going to the market to buy and sell, soon learns how to be both a good home keeper and an astute trader, independent of her mother. The little boy who starts out by assisting his father to farm the family plot of land, and who goes hunting for grasscutters and other smaller animals, soon learns how to farm a sizable plot of land all by himself and how to hunt for bigger game (Moumouni 1968, 20). Moumouni emphasizes this when he states that, "it is by accomplishing productive tasks that the child and adolescent familiarize themselves with adult jobs and are initiated into the different social aspects of their future lives" (Moumouni 1968, 19). Precolonial African education therefore, involves the child being a part of a solid and oftentimes complex relationship - aimed at imparting knowledge_-with the members of his community (Moumouni 1968, 20). 
The education of the African child was essentially pragmatic, "virtue was inculcated more through exercise than through precept" (Abraham 1969, 70). Elders in Africa are renowned for being custodians of knowledge and wisdom, making them the indispensable chief architects in shaping the minds of the younger generation. William Emmanuel Abraham in The Mind of Africa (University of Chicago: Chicago 1969), writing about the Akan of Ghana, states that "the words of one's elders are greater than amulet" (Abraham 1969, 70). Among the numerous sayings of the Akans that show this reverence for age and the wisdom it comes with is that "there was an old man before a lord was born" (Abraham 1969, 71).

As the child approaches puberty in several parts of Africa, education assumes a more formal approach. In preparation for being a fully-fledged adult in the society, the boy child passes through initiation rites at around the age of 15 or 16 (Moumouni $1968,25)$. In most cases, he is taken away to a camp, several miles from the village, where he is taught secrets about the community, which the uninitiated would never be privy. A good and popular example "was the initiation school held by the Poro brotherhood in Sierra Leone" (Rodney 1972, 262). The young men live in groups of about 50 and are constantly instructed by the elders of the village for as long as the ceremony lasts. The young man also undergoes the painful act of circumcision after which he emerges as a real man, ready to get married and start his own family. During the period of seclusion, a strong feeling of camaraderie and trust is built among the group, which binds them together for the rest of their lives. Moumouni asserts that the process of initiation places adequate emphasis on "physical exercises, sexual education, awareness of responsibility and the harmonious acceptance of the child into the community" (Moumouni 1968, 30).

Moumouni identifies four distinct characteristics of traditional or precolonial African education, which distinguishes it from that obtainable elsewhere.

(a) The early emphasis on the development of the child's physical endowments: This is usually achieved through games such as jump rope, races, swimming, acrobatics, and other sports competitions, which might be considered intense for the child. The true test of the child's transition into adulthood for the boy requires weeks, and sometimes months of physically tasking exercises. The overall aim is to develop the child's body, "agility, endurance, physical resistance and ability to use his body in different circumstances and for different purposes" (Moumouni 1968, 21).

(b) The high regard accorded to character building and development: The individual as a moral agent plays a central role in traditional African education. Issues of honesty, integrity and mannerism are taken seriously in the training which the child receives both at home and from the community. A high degree of ethical conduct is expected from the individual by society in all of his dealings. "Sociability, integrity, honesty, courage, solidarity, endurance, ethics and above all the concept of honor are, among others, the moral qualities constantly demanded, examined, judged, and sanctioned, in ways which depend on the intellectual level and capacities of the child and adolescent" (Moumouni 1968, 22). 
(c) Education in precolonial Africa encompassed both physical and intellectual activities at every stage of the child's training. Through the use of age groups, age and sex relevant knowledge is transmitted to the younger generation (Moumouni $1968,25)$. In the Yoruba state of Keta in the nineteenth century, there was in existence, a school of history, where a learned elder and master of Keta history "drilled into the memories of his pupils a long list of the kings of Keta and their achievements" (Rodney 1972, 263). In Muslim communities there existed a large number of institutions of higher learning, such as found in Timbuktu, which provided knowledge in Arabic. Of note is that the mastery of language was greatly emphasized, a state not unconnected with the oral nature of education in precolonial Africa. The mastery of the knowledge of proverbs, idioms, riddles, narration, stories and legends made eloquence in their recitation a much treasured talent. Lawuo (1978) suggests that certain games such as, "dara" or "dili", "wouri" or "awele" "are real exercises in mathematics, which involve geometry, combinations, and the properties of numbers," and these games played in traditional Africa were educational in nature and, at the same time, intellectually stimulating.

African proverbs are deep philosophical truths compressed in one single statement. The unwritten nature of African intellectual experience made the use of proverbs expedient in precolonial times, such that from one single proverb, a whole textbook of philosophical musings could be written were it to be in a society where writing was extensively utilized. A proverb of the Igbo people found in today's south eastern Nigeria which says that one must "search for the black goat while there is still daylight," carries with it the deep philosophical truths about doing things at the right time. So re-echoes the biblical philosopher Solomon when he says in Ecclesiastes that there is time for everything under the sun. Proverbs are widespread across all African societies, and their themes bear strong resemblance to one another from place to place. The Yoruba imply that the world has turned upside down, with the saying that "when an egg drops into an earthen pot, it is the pot that breaks." The Akan harbor similar sentiments when they say that "the lizard which dropped from the top of the coconut tree, nodded his head up and down, and asked the earth if it felt dizzy" (Abraham 1969, 94).

Most African folklore also transcend the entertainment realm, to hold deep and stimulating philosophical truths. Across pre-colonial Africa, the education of the child involved hours of sitting under the moonlight listening to folklores told by the elders in the compound. These stories were undoubtedly both recreational and educative, cutting across disciplines, including; philosophy, literature, law, psychology, music, drama, arts, and sociology to mention few. 
Some of the stories were designed to emphasize the superiority of brilliance over steadiness. For example, the African Tortoise won his race against the Hare not by toiling upward in the night while his companion slept, but by planting in the shrubs along the route several tortoises like him, the last of whom stirred himself to the tape at a suitable time (Abraham 1969, 96).

The need for astuteness, clan unity and the value of cooperative efforts, among other sociological attributes are embedded in this story (Abraham 1969, 96).

Very little attention has been paid to the intellectual expression of African art, which forms part of the education structure of Africa. European curators have drawn from the aesthetic emphasis of European art to interpret African art, although the latter was fashioned mostly for their intellectual, philosophical, and spiritual uses. As most of the education in precolonial Africa was based on orature, Africans tended to express their "philosophic-religious ideas through art, through the timeless, immemorial, silent, and elemental power so characteristic of African traditional art" (Abraham $1969,111)$. African traditional art most often assumes a distorted form and is hardly life-like in its representation. This abstraction often masks a depth of thoughts and theoretical persuasions which most often seek to understand the physical as well as the metaphysical realm. Unfortunately, undiscerning European art critics, by comparing African art with European art, which is primarily for decoration and entertainment, have dismissed African art as being incapable of realistic expression. Abraham opines that in doing so, the Europeans "miss the point of African art. If they seek life-like representation, they should turn to secular art, the art which was produced for decorative purposes or the purposes of records, rather than moral art, the art whose inspiration is the intuition of world force" (Abraham 1969, 111).

Precolonial African education emphasized practical exercises in orature, music, art, history and general knowledge, among others. Moumouni contends that, "precolonial African education responded to the economic, social and political conditions of precolonial African societies and it is in relation to these conditions that it must be examined and analyzed" (Moumouni 1968, 28). He further asserts that traditional African education

was fully capable of supplying the necessary elements to maintain in all its essentials the level attained by African society - before the slave trade - in the economic, social, technical and cultural spheres. In this sense, one can say that it fulfilled its objectives ... even today, the technical achievements, political and economic organization, work of art, the striking personality of older Africans and the intact vitality of the peoples of Black Africa bear witness to this fact (Moumouni 1968, 28).

Precolonial African education adequately supplied the blacksmiths, weavers, shoemakers, and other artisans needed to stimulate the economy of the societies in question. Politically, socially, and culturally, the successes of the several empires and acephalous societies such as kingdoms in Benin, Ghana and Mali or the Igbo of today's southeastern Nigeria demonstrate the effectiveness of traditional African education.

The incursion of Christian proselytes into Africa, occasioned by the end of slave trade was to drastically upturn the status quo in the education system of sub-Saharan Africa. According to the renowned Tanzanian professor of history 
Z. E. Lawuo, in "The Beginnings and Development of Western Education in Tanganyika: The German Period" (in, Ishumi et al., The Educational Process. Dares Salaam 1978, 47-65), the European slave traders only acceded to the call for the abolition of slavery when they made the discovery that it would better benefit them if they allowed the African to stay in their land to plant the crops needed by Europe. To optimally exploit the economic benefits from Africa, the Europeans considered it necessary to change the culture, beliefs, and value system of the African to make him more subservient, and to seal it finally with political colonization. Lawuo contends that the appearance of the missionaries in Africa, together with the Western education they brought, was a direct response to these economic aspirations of Europe;

\footnotetext{
Christian missionaries used education as their tool for gaining converts and making entry into new areas to pave the way for Western socio-economic and political structures. According to David Livingstone, who first came to Africa as a missionary sent out by the London Missionary Society, the most important duty of the European Christian Missionary in Africa was to integrate the African into European economic structures. Africa, he declared, should not be allowed to industrialize, but instead it should serve as a plantation for the metropole, growing the crops demanded by industrial Europe (Lawuo 1978, 50).
}

The task of the Western missionary was therefore twofold, one of Westernizing and another of Christianizing the native. This he tried to achieve through socialization and acculturation packaged in the gospel and in the education that was administered to the natives (Mazrui 1979, 32). In "Churches and Multinationals in the Spread of Modern Education: A Third World Perspective," eminent Africanist scholar Ali Mazrui posits that, "the technological triumph of the western world gave its system of education almost universal prestige. Cultures which previously trained and socialized their children in radically different ways, saw themselves drawn irresistibly towards the western approach to education" (Third World Quarterly, Vol. 1, No. 1 Jan 1979, 30-49). Mazrui argues that paradoxically, the missionary school was the principal medium for transiting Africa from a backward, uncivilized barbaric society to a Western-styled, but now secularized civilization. Missionary education, focused on transmitting the "archival" Christianity-based society to Africa which was a fanatical version of the religion "which most Westerners had already rejected in the course of their own modernization (Mazrui 1979, 32). This desire to plant religiosity at the center of social life, however, did not deter the missionaries from seeking to transplant the modern anti-Christian culture to Africa at the same time "devoutism" was upheld. The ultimate aim was to "produce from the schools, African men and women with modern secular skills necessary for the new society of the twentieth century" (Mazrui 1979, 32).

The resultant "cultural schizophrenia" greatly undermined African culture and values as the now Christianized native left the school vowing to destroy whatever is anti-Christian or indeed anti Western in its minutest representation. Further, the Christian values being dispensed in schools as part of the education package extolled the "virtues of obedience instead of the ethos of initiative," "the fear of God instead of love of country," "the evils of acquisition instead of the strategy of reconciling personal ambition with social obligation” (Mazrui 1979, 35). 


\section{Colonial Education}

Soon after the missionaries established education in Africa, European powers, seeking more profit through the global expansion of capital, formally colonized most of sub-Saharan Africa by the late nineteenth and early twentieth centuries. Charles H. Lyons in "The Educable African: British Thought and Action 1835-1865" (in Battle and Lyons (eds) Essays in the History of African Education. Columbia University: New York, 1970) contends that the export of education to "sub-Saharan Africa coincided with the rise of pervasive racism in Great Britain," which was an outgrowth of the "simplistic empiricism of the enlightenment." The "early Victorian science which was birthed during this period was preoccupied with determining human intelligence through a study of "cranial capacity, ${ }^{1}$ phrenology, and comparative head shapes" (Lyons 1970, 1). At that time, Charles Darwin's publication of his Origin of Species which traced modern homo sapiens to the evolution process and emphasized such terms as "natural selection" and "ascent from lower species," strengthened the argument in favor of the superiority of the caucasian race above all others (Lyons 1970, 12). Lyon submits that "selective use of Darwinian rhetoric, then, was an effective way to give credence to what was before just supposition and to chastise the humanitarians who were progressively losing support in an increasingly science-conscious Victorian society" (Lyons 1970, 12).

The early champions of education in Africa, the missionaries who were humanitarians, did not accept this biased view of a racial difference in intellectual capacity, but maintained the secular view that "the black man was either an actual or potential intellectual equal of the white" (Lyons 1970, 4). In this battle for the mind of the black man, religion and the missionaries who brought education to Africa with the submissions that, "the same God made them all, both black, white, yellow or red; in His image and likeness He created them all," increasingly lost ground to pseudoscience. The colonial government believed in the objectivity of science against the emotionalism of religion, and therefore the scientific reports which extolled evolution and the difference in species formed the basis for the making of the colonial government education policy (Lyons 1970, 7). The authority of the missionaries in the education of the natives of sub-Saharan Africa was soon displaced by the colonial authorities, ably leaning on the intellectual acumen of the racist anthropologists and ethnologists for their colonial policies. ${ }^{2}$

\footnotetext{
${ }^{1}$ Lyon observes that "in the Anthropological Society of London, for example, President Hunt relied on evidences of comparative "facial angles" to show that the black African was decidedly inferior, intellectually, to the European" (Lyons 1970, 8).

${ }^{2}$ Several members of the Anthropological society would assert at that time that, "the brain of the black African looked very much like the brain of a European in its infant age. At puberty, all development in the brain of the Negro ceased and it became more ape-like as it grew older" (Lyons 1970, 9). Others would contend that "black children had not such retentive memories as white children and that... they came to a state of status quo at about 16, and after that slowly forgot all that they had learnt." The Anthropological Society's vice-president Richard Burton, had said much the same thing in an earlier publication in 1860, when he observed that "the African preserves the instinct of infancy in later life... He astonished the enlightened Da Gama some centuries ago by
} 
The first missionary group to establish formal Western-styled education in British West Africa did so towards the end of the eighteenth century, when the Society for the Propagation for Gospel established a mission school in Gold Coast (Lyons 1970, 14). The Anglican-sponsored Church Missionary Society (CMS) established the first school in Freetown Sierra Leone in 1806 and, about 5 years later, the Wesleyans. By 1841 there were at least "6,600 African students of one sort or another in schools in Sierra Leone, and another thousand or so in the Gambia and the Gold Coast" (Lyons 1970, 14).

As the schools grew in student population, there was the ever-increasing need for more teachers from the home country of the missionaries. F. H. Hilliard, in A Short History of Education in British West Africa (London: Thomas Nelson 1957, 1-7) asserts that the increased teacher population coupled with increased remuneration and terms of service soon went beyond the scope of the charity money which was trickling in for the missionary organizations. Soon the British Government was significantly assisting in meeting the financial obligations of the missionary schools, although the program content remained entirely religious in approach.

In 1842, the British Parliament appointed a Commissioner, Dr. Richard R. Madden, M. D. to "investigate among other things, the conduct of mission education in West Africa, and to make recommendations for its improvement." Richard Madden in "Report of Her Majesty's Commissioner on the State of British Settlements on the Western Coast of Africa: Climate and Its influence on Health" (in "Report of 1842," XII, 430), submits that the intellectual faculties of the African thrives most when he is between the ages of 5-12 and from then on it begins to experience a decline. According to him, the harsh climatic environment forces the "premature development" of the brain of the African in his early years, and unfortunately, those were the years spent in "memorizing sums and letters, things he will rapidly forget in later years." In submission, Madden called for the drafting of a curriculum rich in mechanical, and farming courses, rather than one geared toward intellectual development; "do not teach the child to follow intellectual pursuits which he can never master; instead, teach the young to work" (in "Report of 1842," XII, 430).

Other commissions later set up gave submissions that did not differ drastically from that of Dr. Madden. The reports of the several instituted colonial education commissions were filled with racist jargon, which drew from the prevailing views of the incapability of the black man to assimilate, retain, and process knowledge (Lyons 1970, 13). The crux of the argument was that literary education should be deemphasized and trainings in petty industry, farming, and mechanical work be given precedence as early as possible. Lyons opined that this stance is also not unconnected with the desire of the government to ensure that "the number of educated Africans correspond to the small number of clerical positions available" (Lyons 1970, 17).

Owing to the increased interest of the colonial government in African education, the governors of the Gambia, the Gold Coast, Sierra Leone, and later Lagos became increasingly interested in the educational structure and content within their respective

rejecting with disdain jewels, gold, and silver, whilst he caught greedily at beads and other baubles, just as a child snatches at a plaything" (Lyons 1970, 9). 
colonies. This heightened interest and curiosity led them to scrutinize the activities of the missionaries, and in more cases than not, to declare that the education the missionaries rendered was inappropriate and not suited to the intellectual disposition of the natives. In 1849, for instance, the Acting Governor-General Pine of Sierra Leone condemned in very strong terms, the missionary program of education within the settlement, dismissing it as too bookish and "unsuited to the requirements of the people," considering their low intellectual aptitude and culture. Pine warned the missionaries to desist from unnecessary emphasis on "abstract learning" and to focus on training in "a practical knowledge of agriculture and mechanical arts for which Africans were more fitted" (Benjamin W. Pine, Acting-Governor of Sierra Leone, Annual Report for 1848, Parliamentary Papers, 1849, XXXVI, 306). His successor Governor Norman Macdonald continued along the same line when he stated expressly that the curriculum in West African education should be completely overhauled and reworked to a simplified version that will ensure that the boys are thoroughly educated in the form of education that "will enable them hereafter to gain an honest living in that humble sphere of life in which the lot of them is cast." In his published Annual Report for 1851, The Governor singled out Sierra Leone's Fourah Bay College and new Grammar School for special rebuke. He strongly urged Her Majesty's government to persuade the CMS to adopt a more sound and useful course of education, one best suited to the mental capacities of the youth" (Norman Macdonald, Governor of Sierra Leone, Annual Report for 1851, Parliamentary Papers, 1852, XXXI, 183).

The missionaries would not easily accept the denigration of their converts by the colonial authorities. Although they generally agreed that the African was in comparison to the Briton, less industrious, the missionaries differed from the scientists, by attributing this to the extreme heat of the tropics in addition to the abundant supply that nature had offered the African, making the need to work for survival less of a priority. The missionaries believed that the African must be made to imbibe the protestant ethic that placed hard work next to holiness, in order to get him to work as hard as the Britons. The colonial governments disagreed entirely with the missionaries' viewpoint, dismissing it as futile. T. J. Hutchinson, The British Consul for the Bights of Biafra and Benin in the 1860s, in his article "On the Social and Domestic Traits of the African Tribes" (Transactions of the Ethnological Society of London (TESL), 1861, 316-326) in his remarks on the education of Africans, would assert that no amount of mission education could ameliorate the inborn slothful dispositions of the African. He emphasized the unproductive nature of missionary education, saying that with that kind of education, "ages must elapse before any educational principle in its simplest form can produce an amendment on temperaments such as the African possesses" (TES, 1861, 316-326). For teaching the natives Latin, Greek, Hebrew, literature, geometry, arithmetic, physics and the same form of education obtainable in Europe, tempered with a strong religious bias, the missionary education in British West Africa was dismissed as lacking in authenticity. A similar situation was also observable elsewhere in the areas colonized by the French.

Until the early twentieth century, the colonial governments more or less assisted in funding the schools run by the missionaries and made suggestions as to the curriculum without being too overbearing. At the end of WWI, after the allied forces had declared 
victory over imperial Germany, it became more eminent that the colonizing powers of Britain and France stood to gain from becoming more involved in the colonial process. First and certainly most important was the economic benefits accruable from the colonies, who would henceforth act as the suppliers of raw materials to feed the growing and booming factories of the colonialists. Second, the post-war mentality of readiness to fight, even in times of apparent peace, convinced both colonial powers that their colonies could be utilized as "strategic bases from which to attack the colonies of the adversary" (Moumouni 1978, 38). In addition, the use of black soldiers to fight in WWI occasioned their preservation as canon fodders in the case of another war in the near future. In French West Africa, for instance, it was a battle for acculturation of the African mind in order to assure France of the loyalty of her African subjects. By alienating the African as much as possible from his culture, France was able to economically maximize the benefits accruable from colonialism without much dissent from the colonized. The most strategic tool for this cultural acculturation was the colonial education policy. In the words of M. Brevie, the Governor-General of French West Africa, which he stated before the Government Council of French West Africa

The duties of colonialism and political and economic necessities have imposed a twofold
task on our work in education. On one hand, we must train indigenous cadres to become
our auxillaries in every area, and assure ourselves of a meticulously chosen elite. We must
also educate the masses to bring them closer to us and transform their way of living... from
the political standpoint we must make known to the people our intention of bringing them
into the French way of life... From the economic viewpoint we must train the producers and
consumers of tomorrow... the content of our school programs is not simply a pedagogical
affair. The pupil is an instrument of indigenous politics (Moumouni 1978, 43).

In the text of the decree of May 10, 1924, which reorganized education in French West Africa, it stated quite clearly, the reasons for embarking on the education of the natives as follows:

Article 5: Attendance in school should be obligatory for the sons of chiefs and notables.

Articles 9: The best student from the preparatory school, those who understand and speak French, shall be directed to the nearest elementary school and continue directly on for the Certificat d'etudes primaries indigene (CEPI). The others, constituting the large majority, will be returned to their families and replaced by an equal number of young recruits in order that the largest number of children will be given an introduction to the understanding and use of spoken French.

Article 2: The essential goal of elementary education is to bring the greatest possible number of indigenous people closer to us, to familiarize them with our language, our institutions and our methods, to lead them gradually towards economic and social progress by the careful evolution of their own civilization.

Article 32: The goal of advanced primary education is to provide general education in each colony:

1. To give additional instruction to the sons of local notables who will later be called on to assist our administration as chiefs.

2. To prepare candidates for the schools of the Governor-General, in order to supply native officials for general administration. 
3. To train officials for local administration. The number and nature of the sections will vary according to the needs of the colony.

Article 64: French will be the sole language in the schools. Teachers are forbidden to use local languages with their students (Moumouni 1978, 45).

In British West Africa, the same philosophical undertones defined colonial education. Walter Rodney cites the example of the Bemba of Ghana who, when the children went to school, were taught about European roses flowers and plants, which bore no resemblance with the plants and flowers observable within their own society. Walter Rodney quouted a Dr. Kofi Busia;

At the end of my first year at secondary school (Mfantsipim, Cape Coast, Ghana), I went home to Wenchi for the Christmas vacation. I had not been home for four years, and on that visit, I became painfully aware of my isolation. I understood our community far less than the boys of my own age who had never been to school. Over the years, as I went through college and university, I felt increasingly that the education I received taught me more and more about Europe and less and less about my own society (Rodney 1972, 270).

More poignant is the fact that on a hot afternoon in West Africa, school children were being taught that the four seasons of the year was - spring, summer, autumn, and winter. Rodney regrets that "Europeans thoughtlessly applied their own curricula without reference to African conditions; but very often they deliberately did so with intent to confuse and mystify" (Rodney 1972, 271). African children were being taught about the Alps and river Rhine, but nothing about the Niger, Nile, Congo, or Zambezi rivers. Instead, African pupils were taught that Mungo Park "discovered" the Niger River, and were forced to memorize the names of other Europeans who "discovered" Mount Kenya, Lake Victoria, and other indigenous African heritage sites. Writes Rodney,

As late as 1949, a Principal Education Officer in Tanganyika carefully outlined that the Africans of that colony should be bombarded in primary school with propaganda about the British royal family. "The theme of the (British) king as a father should be stressed throughout the syllabus and mentioned in every lesson" he said. "African children should be shown numerous pictures of the English princesses and their ponies at Sandringham and Windsor Castle" (Rodney 1972, 271).

Certain governors tried to protect the indigenous knowledge of the African in the education curricula but came under intense criticism by the colonial authorities in the motherland. In the 1920s, Governor Cameron of Tanganyika was one of the rare enlightened minds among the Governors who sought to preserve the personality of the African through the academic curricula designed for him. However, he was very seriously reprimanded and called in for questioning, in response to which he denied the charges, for fear of losing his job, claiming instead, that "his intention was that the African should cease to think as an African and instead should become a fairminded Englishman" (Rodney 1972, 272). The missionary schools of Livingstonia and Blantyre in Malawi produced Scottishmen in black skin. Amilcar Cabral (1980, 45) writes in Unity and Struggle (London: Heinemann) that "colonialism by denying the dominated people their own historical process, necessarily denies their cultural process." 
Peggy Ann David (1986) in the dissertation, "The African People of Guyana: A Study of Social Organization During the Colonial Period" (Howard University Department of African Studies), rightly divides colonial education policy in Africa into education for adaptation; intended to produce only "wage laborers and simple peasant producers," education for control; directly enforced through the curricula, corporal punishments and teaching practices, and education for cultural colonization which sought to produce Europeanized Africans (David 1986, 86). David asserts that colonial education was of a far more inferior quality than what was obtainable in the countries of the colonizing powers for several reasons. Following the widely accepted scientific notion of the low intellectual capacity of the African, the curriculum was designed to embody only the level of knowledge which the African was deemed to be able to absorb at any given time. Africans were given just about enough education to enable them understand the language and ways of the European, so that upon graduation, it will be a seamless transition to the position of a clerk, messenger, typist or other low level job in the colonial bureaucracy. Here, mastery of the colonial language, became a prerequisite for admission into post-secondary schools, and in this instance, several brilliant students who were not good at languages lost out.

\section{Language of Instruction and Dependency}

During colonial times, the languages of the imperial powers occupying each country in Africa became the official language of communication and learning. French, English, and Portuguese were used in teaching at varying degrees all over colonial Africa. The Kenyan author, Ngugi Wa Thiong'o (1987) who has written extensively on the language policy of Africa, writes in Decolonizing the Mind: The Politics of Language in African Literature (London: Heinemann), that the end of colonial rule signaled the end of the "sword and bullet" and the commencement of the "chalk and blackboard" of the colonizers as a means of subjugation of Africa. It was through acculturation, achieved through the education process and the language of communication that the colonialists succeeded in controlling not just the resources and state of Africa, but most frighteningly, his mind as well. In Decolonizing the Mind, Wa Thiong'o (1987) notes that the erosion of cultural pride makes Africans want to identify with other peoples' languages rather than their own. He relates the incidence observable in his days of growing up in rural Kenya, where he spoke his mother tongue Gikuyu, at home and in the fields, but at school, his language of education ceased to be the language of his culture and thoughts. The child who was caught speaking his heart language, Gikuyu within the school premises was subjected to corporal punishment or fined money. Those who spoke English were admired as the intelligent ones, and English, according to Wa Thiong'o, "became the main determinant of a child's progress up the ladder of the formal education" (Wa Thiong'o 1987, 12). 
In a paper delivered in 2003, titled "Consciousness and African Renaissance: South Africa in the Black Imagination" which was delivered at The Fourth Annual Steve Biko Memorial Lecture, at the University of Cape Town, South Africa, Wa Thiongo explained culture as being central to a society's progress, and language as the major vehicle of culture. This implies that language is important in shaping the consciousness of the individuals that make up society. Realizing this truth, the outgoing colonialists ensured that their languages and therefore, their cultures were retained by the ex-colonies. Culture transmits world imagery through the spoken and the written language. Unfortunately for the colonial child, his exposure to written language brought with it a forceful initiation into the culture of Europe, while his own culture and language were demeaned as not upscale enough to merit intellectual or academic attention (Wa Thiong'o 1987, 12).

Apart from Tanzania whose immediate post-independence government was able to institute Swahili as the national language and language of education at the primary and post-primary levels, most other African countries at the end of colonialism, were unable to overhaul the linguistic inheritance of the colonialists in the educational sector.

Colonial education aimed at the devaluation of not just the African language but the debasing of the culture it embodies, such as "art, dance, religion, history, geography, education, orature and literature, and the conscious elevation of the language and culture of the colonized" (Wa Thiong'o 1987, 16). In this regard, Wa Thiong'o stresses that while Africans routinely exclude their language and culture, losing sight of who they are and ignoring their essence, the Christian Bible is available in, "unlimited quantities in even the tiniest African language" (Wa Thiong'o 2003, 26). The proselyte from Europe having a strong faith in his mission of mental and spiritual conquest made sure he communicated in the heart language of his target audience, while the African writer, on the contrary, lacked faith in the ability of his indigenous language to carry the weight of his thoughts and experiences.

Obanya (1980) concurs with Wa Thiongo when he asserts that

It has always been felt by African educationists that the African child's major learning problem is linguistic. Instruction is given in a language that is not normally used in his immediate environment, a language which neither the learner nor the teacher understands and uses well enough (Obanya 1980, 66).

Fanon (1963) in The Wretched of the Earth (Paris: Presence Africaine) notes that cultural imperialism is the worst form of imperialism since it effectively destroys the memory, values and unique consciousness of the colonized, and forces an alien memory on him. In Fanon's words

Every colonized people... in whose soul an inferiority complex has been created by the death and burial of its local originality - finds itself face to face with the language of the civilizing nation; that is with the culture of the mother country. The colonized is elevated above his jungle status (in his eyes) in proportion to his adoption of the mother country's cultural standards (Fanon 1963, 18). 
Of note is that the most famous African education commission set up by the British colonial government—-the Phelps-Stokes Fund Report of $1922^{3}$ — recommended the use of indigenous languages as languages of instruction for African schools. According to the report,

with full appreciation of the European language, the value of the Native tongue is immensely more vital, in that it is one of the chief means of preserving whatever is good in native customs, ideas and ideals, and thereby preserving what is more important than all else, namely, native self-respect. All peoples have an inherent right to their own language... No greater injustice can be committed against a people than to deprive them of their own language (Lewis 1962).

Contrary to the recommendations of the Phelps-Stokes Commission, Africans felt differently about studying in their mother tongue and resisted the policy fiercely, contending that it served to perpetuate the racial arrogance of the colonial powers by depicting the African as incapable of assimilating knowledge packaged in the English language. ${ }^{4}$ In Whose Education for All: The Recolonization of the African Mind, (New York: Falmers Press), Brock-Utne (2000) asserts that the Africans rejected the systems supposedly tailored to their needs and demanded to be educated to exactly the same standards as the Europeans (Brock-Utne 2000, 147). Ali Mazrui (2003) in Africa and Other Civilizations: Conquests and Counter Conquests. (New York: Africa World Press) notes that African universities are mentally dependent on the West and engaged in wholesale imitation of Western educational systems-including the medium of instruction. He further emphasized that no African intellectual or researcher can carry on a scientific or advanced academic discussion in an African language.

\section{Effects of Colonial Education}

The lingering effect of the type of education which was imposed on most of Africa can be experienced in the lack of creativity and innovation, which are the hallmarks of Africa's education system. Commenting on this, Walter Rodney in How Europe Underdeveloped Africa notes that

Education is crucial in any type of society for the preservation of the lives of its members and the maintenance of the social structure... The most crucial aspect of pre-colonial African education was its relevance to Africans in sharp contrast with that which was later introduced under colonialism... The main purpose of colonial school system was to train Africans to participate in the domination and exploitation of the continent as a whole... Colonial education was education for subordination, exploitation, the creation of mental confusion and the development of underdevelopment (Rodney 1972, 263).

\footnotetext{
${ }^{3}$ The fund was a philanthropic American organization which had helped establish a segregated educational system for black Americans and based on the "successes" recorded in America, was requested by the British to organize a similar system for their colonies.

${ }^{4}$ The suspicion of the Africans was that the language policy was designed to keep them in the social ghettoes just like the black Americans whose education is inferior to the whites.
} 
Colonial education succeeded in its aim of preparing Africans for subordinate positions available to natives within the structure of the colonial bureaucracy; interpreters, clerks, teachers, hospital workers, and other needs of the administration. The result was the production of civil servants who were dedicated to the service of the colonizing powers and indeed regarded themselves as the highly privileged few as compared to the majority of their brethren. In Decolonising the Mind, Ngugi Wa Thiongo stresses that the "Berlin conference of 1884 was affected through the sword and the bullet. But the night of the sword and the bullet was followed by the morning of the chalk and the blackboard. The physical violence of the battlefield was followed by the psychological violence of the classroom" (Wa Thiong'o 1987, 9). Along with the magnitude of servility displayed to their white supervisors, the newly educated African elite also treated their fellow Africans with scorn and arrogance, thereby propagating the myth of "white superiority" and black inferiority (Moumouni 1968, 49).

Arising from a syllabus that extolled the virtues of the white race and the civilizing mandate of Europe towards a barbaric African race, the newly educated elite "could not conceive of a future for their country outside servile submission to the colonial yoke" (Moumouni 1968, 49). Whatever strength of character, belief in himself, his environment and community that the educated African previously had was soon replaced by complete detachment from his own people and an attitude of intense and desperate imitation of any semblance of Whiteness. According to Cheikh Hamidou Kane in Ambiguous Adventure (1972),

On the Black Continent, one began to understand that their real power resided not at all in the cannons of the first morning but in what followed the cannons. Therefore behind the cannons was the new school. The new school had the nature of both the cannon and the magnet. From the cannon it took the efficiency of a fighting weapon. But better than the cannon it made the conquest permanent. The conquest forces the body and the school fascinates the soul.

Colonial education sought to systematically devalue Africa's indigenous knowledge and to destroy all sense of self, community awareness and pride, which the African had prior to being engrafted as a part of the colonial system. Walter Rodney declares that "the educated Africans were the most alienated Africans on the continent. At each further stage of education, they were battered and succumbed to the white capitalist system, and after being given salaries, they could then afford to sustain a style of life imported from outside... that further transformed their mentality" (Rodney 1972, 275).

Owing to the overwhelming evidence of technical and economic advancements by the colonial powers, even the uneducated and half-educated Africans, began to strive to be like the "Whiteman," to the detriment of being true to their authentic selves. The educated African soon became trapped in the desire for ever more acquisition of the manifestations of capitalism in the form of wealth-ostentatiously displayed in the form of houses, cars, apparel, and frequent overseas visits. The more they endeared themselves to the colonial authorities, the more they were rewarded and the more they treated their fellow Africans with disdain.

Colonial education, by de-personalizing the African, succeeded in the corruption of his thought processes and perceptions, such that he began to think abnormally 
and in a warped and self-hating sort of way. The way of thinking of Africans taught in the classrooms, and their uneducated counterparts, whom they interacted with outside the classroom assumed a self-denigrating pattern. In particular, the colonial education of the French, Belgian, and Portuguese which tried to assimilate Africans into their own culture resulted in an almost total annihilation of the personhood of the African. Fanon succinctly explained it when he wrote that; "culture has never the translucidity of custom; it abhors all simplification. In its essence, it is opposed to custom, for custom is always the deterioration of culture. The desire to attach oneself to tradition or bring abandoned traditions to life again does not only mean going against the current of history, but also opposing one's own people" (Fanon 1963, 224).

At the basic level, the African had to prove himself to be completely bereft of his Africanness in order to be accepted to a reasonable degree by the colonizer as being human at all. Moumouni contends that, "the attraction of the foreign culture was a normal consequence of the desire to expand one's intellectual horizons, and more particularly, of an almost total ignorance of African history and the historical significance of colonialism" (Moumouni 1968, 55).

Speaking on the congenial inferiority occasioned by colonial education, Richard Mollard writes in Hommage a Richard Mollard,

In any case, the "civilized" and civilizing White, good or bad - perhaps above all good began in most cases by persuading the Black that it was a humiliation to be Black, that there is no civilization except the white one. They became unanimous on this point, "My parents are savages," the evolue tells you himself, if he has the rare courage to speak to a White of his origins, which he thinks are shameful... It is understood that the Negro is a savage; sometimes a cannibal, more often as docile as a faithful dog; in short, contemptible and despised; naked, unable to write, incapable of inventing a thing as simple as a wheel or anything that turns; unable to defend himself effectively; he laughs when you show him a zipper; he calls every civilized way of doing things "the way the Whites do it." In short, to be Black is a taint (Richard Mollard, Hommage a Richard Mollard, Paris: Presence Africaine, 1953, pp. 341-62, 368-9) in Moumouni 1968, 56).

The contemptibility displayed towards the African during colonial times differed markedly from the way other colonies or colonized peoples across the globe were treated. Perhaps, this is attributable to the fact that the other civilized cultures such as the Hindus, or the Japanese were never enslaved. Skin color aside, there is also the probability that the interaction between the West and Arabs, Hindus, Chinese, Japanese, and other cultures dated back to a period when these civilizations were on par with Western civilization (Moumouni 1968, 57). Richard Mollard tries to make sense of this peculiarity

This problem is unique to the Negro world. It hardly exists, at least not in the same way, among the other non-western people in the world. Not only were Europeans unable ever to persuade the Arabs, Hindus, Cambodians, Chinese and Japanese that they were savages, primitives, grown-up children and born slaves..., but they themselves began to believe, little by little, that these people, however picturesque and strange they seemed, had their contributions to make, their learning, their civilizations... One may think of this what one will, certainly, but it is incontestable. Also, these people can energetically demonstrate their existence, and at times their opposition, to the "civilizing mission" of Westerners whom they consider miscreants, materialists and intruders (Moumouni 1968, 52). 
In contrast to the colonially imposed view of Africans as savages, the colonialists displayed a much different disposition towards other colonies such as India. Jai Kishan Sharma in Education for Third World Countries: With Special Reference to India (B.R. Publishing: New Delhi, 1986) notes that the respect for the culture and indigenous knowledge of colonial India by the Imperial British powers was manifest in a scheme "post-War Educational Development in India," established by the colonial government in 1944. Writing his observation about the state of education in India, then Governor Sir John Sargent notes in the report, "I have no hesitation in insisting that the foreign system of education at present prevailing in India has, to a large extent, corrupted India's mentality... its effect has been to imprison those associated with it, in, at present, inescapable servitude of foreign mindedness." Prior to making this observation, which formed the bedrock of education in a post-independence India, a scheme had been drawn up in October 1937 at Wardha India. The Wardha scheme was chaired by Mahatma Gandhi under the aegis of an All India National Educational Conference. Among its several recommendations, was the granting of free and compulsory education in the mother tongue, the structuring of curriculum around indigenous knowledge, among other structural and technical transformations (Sharma 1986, 34). The Sargent and Warhda schemes were the foundations upon which the contemporary education system in India was formed.

In a post-colonial India, the basics of the Indian society forms the foundation, but a lot has been borrowed from the Western system. Education in contemporary India seems to have imbibed to a reasonable degree, the principle of Samyakvada or integration, as stated by Sharma. Samyakvada entails the recognition that no distinct philosophy of education, be it Western or traditionally Indian, can meet the needs of the contemporary Indian society. Sharma asserts that it dawned on the government that a new way of education must be embarked upon as a matter of urgency for India to develop after the end of colonial rule. This led the government of the day to state categorically that, "it is beyond argument that we shall have to devise our own system, a system which should be completely and neatly our own in content and form; an imported system of education will only act as a pill of poison for the dying nation to hasten its doom" (Sharma 1986, 37). Sharma decries the present decay of the Indian social theory of Varna, which extols the values of cooperation, complementarity, cohesion, and interdependence. This decay has been occasioned by the spirit of competition and the diversion of the interest of Indians from the deep love for truth, enlightenment and self-realization towards mundane utilities and quick gains. Varna drew Indians to the recognition of individual fulfillment that is tied to societal fulfillment, while the advancement of the Western education philosophy, which glorified science, fostered competition and the formation of groups around "interests, economic or social, political or religious" bred disparities and divisions. India's effort towards returning to the Varna spirit was not necessarily a matter of going back verbatim to the traditional way of life, for that would be parochial and unprogressive (Sharma 1986, 39). It simply entails the integration of science and technology with the authentic Indian values; ridding the spirit of the Indian of the corruption imposed by Western education, its penchant for a lust for power and materialism and repudiation of cooperation, love for truth and nonviolence. Making 
India "a society by the past in the present but for the future; heritage from the past has to be preserved, grown and enriched for posterity" (Sharma 1986, 43).

Unlike the situation in India, post-colonial African leadership did not attach much importance to curriculum transformation at the end of colonialism. Those who did, such as Julius Nyerere and Jomo Kenyatta, could only sustain the transformation until the need arose to seek external funding to sustain the education sector. In Decolonising the Mind, Ngugi Wa Thiong'o (2003) maintains that colonial education made the African view his history with much disdain, as a "wasteland of non-achievement" and one which the African would rather distance himself from, than embrace. Colonial education made the African want to identify with that which was furthest removed from himself and to loathe that which he is or which belongs to him. Fanon writes that, "in the man of color, there is a constant effort to run away from his own individuality, to annihilate his own presence" (Fanon 1967, 60). The result of colonial education was a perpetual psychic dominance of the colonizing power and a psychic submission by the colonized (Wa Thiong'o 2003), such that even the handover of power to the colonized in the name of independence did not change this fact.

On a positive note, colonial education rather than incite a sense of bewilderment and servitude in some, actually engendered a thirst for more knowledge, and mindset that sought to shed light on their subjective situation. These select educated civil servants viewed with much discomfort, the adulation of the colonialists by their ilk, despite the obvious "racist affirmations of the colonial propaganda" (Moumouni $1968,50)$. This tiny minority amongst the educated Africans, at the expense of their career and lives in certain cases, refused to pay obeisance to the colonialists and became marked men, termed a negative influence on the docile populace.

Western education has been the most revolutionary of all influences operating in sub-Saharan Africa since the imposition of European rule. It has been the instrument to the creation of a class indispensable for imperial rule, but one which invariably has taken the leadership in challenging and displacing that rule (Coleman 1960, 278).

It was to an extent the behavior of these few educated citizens which ignited the nationalist passion in the rest of the masses resulting in the ensuing struggle for and granting of independence to the formerly colonized peoples of Africa, an event that occurred mostly in the 1960s.

\section{Culture, Education, and Dependency}

Colonialism caused a drastic shift in the cultural paradigm of African societies. The transplantation of the European education system, which lacked any resemblance to the African environment and culture, brought about a distortion in perception in such a way that alienated Africans from the realities of their environment. Mazrui (2003) opines that Western education has eroded several African cultural values, such as reverence for elders, and solidarity between age peers. What is now observable is a forceful attempt to box African identity within social classes as is observable in 
the West. In the Western liberal principles, the individual as the unit of identity is promoted, unlike Africa's principle of social cohesion and collective responsibility. Western education has also assisted in changing the taste, morals, and other values of the African. Mazrui asserts that, "there is little doubt that African concepts of what is proper or improper, just or unjust, attractive or repulsive have now been profoundly influenced by that system of education of which the university is the pinnacle" (Mazrui 2003, 78).

The change in values has changed the motives for behavior and conduct. "Western individualism and the erosion of traditional restraints" have in many cases resulted in the desire for quick wealth and conspicuous consumption (Mazrui 2003, 79). The impact of the "bureaucratic bourgeoisie" on consumption patterns in Africa according to Mazrui, has been much more profound than any meaningful contribution to technological and economic advancement (Mazrui 2003, 79). Western education has facilitated the desire for quick wealth without the concomitant entrepreneurial foundation. In pursuit of wealth for the purpose of ostentatious expenditure, long-held African values such as deference for elders, solidarity between age groups, character and integrity have been swapped for intense competition, corruption, and wide-scale embezzlement. Through acculturation and normative diffusion, colonialism was able to "constitute a major shift in the cultural paradigm of African societies" (Mazrui 2003, 79).

Colonialism was an intense and sustained process of social, psychological, and to some extent, physical violence against Africa. Although the political, economic and structural control of Africa by European powers can be said to be technically over, the psychological residue of colonialism, implanted as a result of the colonial educational process tarries on the continent. Bulhan R. in Frantz Fanon and the Psychology of Oppression. (New York: Plenum Publishing 2003, 53) explains that one of the consequences of violent experiences is that it distorts the developmental process of the receiver, limiting productivity and indeed causing death. This death is more psychological than physical in nature and directly refers to the death of creativity and innovation in the mind of the violently manipulated. Essentially, colonialism as has been demonstrated through the institution of education, succeeded in embedding a sense of inferiority in the African, thereby fostering a situation of dependency on the colonial powers for the day to day sustenance of the colonized. Unsurprisingly, at the end of colonialism, not much changed in the dependency syndrome inflicted on the formerly colonized peoples of Africa. According to Moumouni, "common sense is enough to prove that the result of so many years of tenacious effort and deliberate action on the part of colonialism cannot be made to disappear overnight" (Moumouni 1968, 54).

Through education, colonialism entrenched abnormal behavior and thinking in Africans, such that even after the acquisition of political freedom from the erstwhile colonial powers, not much change has been effected in the area of education transformation. Apart from slight and mostly structural changes, the existing reality is that African countries have not addressed the core of the education curricula to reflect mental and psychological independence. African leaders for several reasons, which shall be addressed, have not deemed it a matter of paramount importance to 
overhaul the education process, particularly in the area of program content, to reflect the now independence thought and spirit of the African masses. In an independent Africa, the outcome of colonial education still makes the African identify with foreign concepts, knowledge, so-called foreign experts and consultants, and devalue the indigenous, home grown knowledge and more qualified experts on the continent. As has been earlier proven in this text, in contrast to most of sub-Saharan Africa at Independence, India involved itself in a massive transformation of the education sector through the efforts of the visionary Mahatma Gandhi and some other protégé of his, leading to India's great strides in the area of innovative and creative education in the contemporary global economy.

Several decades after the end of colonialism, sub-Saharan Africa has not made much progress in liberating the education process from the clutches of imperialism and dependency. Only marginal improvements have been recorded, such as, increased rate of enrolment, expanded infrastructures, training, and recruitment of more teachers and other improvements that are peripheral to the core issue of curriculum transformation. African pupils and students graduate from different levels of education, with a sense of helplessness, inferiority and deference to Europe. In other words, the more the African studies, the deeper his inability to utilize his knowledge to directly and progressively influence his immediate environment for the better.

\section{References}

Abraham W (1969) The mind of Africa University of Chicago, Chicago

Brock-Utne B (2000) Whose education for all: the recolonization of the African mind. Falmers Press, New York

Coleman JS (1960) The politics of Sub-Saharan Africa. In: Almond GA, Coleman JS (ed) The politics of the developing areas. Princeton University, Princeton, New Jersey

David PA (1986) The African people of Guyana: a study of social organization during the colonial period. Dissertation, Howard University, Department of African Studies

Fanon F (1963) The wretched of the earth. Presence Africaine, Paris

Hilliard FH (1957) A short history of education in British West Africa. Thomas Nelson, London

Kane CH (1972) Ambiguous adventure. Melville House Publishing, New York

Lawuo ZE (1978) The beginings and development of western education in Tanganyika: The German period. In: Abel GM, Ishumi, Mmari GR (eds) The educational process. Theory and practice, with a focus on Tanzania and other countries. Department of Education, University of Dares Salaam, pp 47-65

Lewis LJ (1962) Phelps-Stokes reports on education in Africa. Oxford University, Oxford

Lyons CH (1970) The educable African: British thought and action 1835-1865. In: Battle VM, Lyons CH (eds) Essays in the history of African Education. Center for Education in Africa, Institute of International Studies Teachers College, Columbia University, New York

Macdonald N (1852) Governor of Sierra Leone, Annual Report for 1851, Parliamentary Papers, XXXI, 183

Madden R (1842a) Report of Her Majesty's Commissioner on the State of British Settlements on the Western Coast of Africa: Climate and Its influence on Health. "Report of Her Majesty's Commissioner" (XII) 430

Madden R (1842b) Report of Her Majesty's Commissioner on the State of British Settlements on the Western Coast of Africa: Climate and Its influence on Health, in Report XII 430 
Mazrui A (1979) Churches and multinationals in the spread of modern education: a third world perspective. Third World Q 1 (Jan) 30-49

Mazrui A (2003) Africa and cultural dependency: the case of the African University. In: Mazrui AA, Falola T (eds) Africa and other civilizations; conquests and counter conquests-The collected essays, vol 11. Africa World Press Inc., New Jersey, pp 57-94

Moumouni A (1968) Education in Africa. Praeger, New York

Obanya PAI (1980) General methods of teaching. Macmillan, London

Pine BW (1849) Acting-Governor of Sierra Leone, Annual Report for 1848, Parliamentary Papers, XXXVI 306

Rodney W (1972) How Europe underdeveloped Africa. Bogle L'Overture, London

Sharma JK (1986) Education for third world countries: with special reference to India. B.R. Publishing, New Delhi

Wa Thiong'o N (1987) Decolonizing the mind: the politics of language in African literature. Heinemann, London

Wa Thiong'o N (2003) Consciousness and African Renaissance: South Africa in the Black Imagination. In: The fourth annual Steve Biko Memorial Lecture, University of Cape Town, South Africa. September 2003

Open Access This chapter is licensed under the terms of the Creative Commons Attribution 4.0 International License (http://creativecommons.org/licenses/by/4.0/), which permits use, sharing, adaptation, distribution and reproduction in any medium or format, as long as you give appropriate credit to the original author(s) and the source, provide a link to the Creative Commons license and indicate if changes were made.

The images or other third party material in this chapter are included in the chapter's Creative Commons license, unless indicated otherwise in a credit line to the material. If material is not included in the chapter's Creative Commons license and your intended use is not permitted by statutory regulation or exceeds the permitted use, you will need to obtain permission directly from the copyright holder.

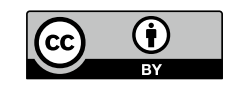

